\title{
An Overview of the Economic Causes and Effects of Dollarisation: Case of Zimbabwe
}

\section{Lionel Nkomazana}

\author{
Student, Vaal University of Technology
}

E-mail:nkomazanalionel@gmail.com

\section{Ferdinand Niyimbanira}

Lecturer in Economics, Vaal University of Technology E-mail:ferdinandn@vut.ac.za

\section{Doi:10.5901/mjss.2014.v5n7p69}

\section{Abstract}

Zimbabwe acquired its independence on 18 April 1980. Thereafter, its government introduced the currency known as the Zimbabwean dollar (ZW\$) as an official currency, replacing the Rhodesian dollar in equivalence. At its inception, the Zimbabwean dollar had an exchange rate of one to 1.47 United States dollars (US\$). However, according to Sikwila (2013:398), "by July 2008 its value had dropped to ZW\$10 billion to 0.33 US\$. This was fuelled by the substantial increase in money supply of ZW\$20.5 trillion." The increase led Zimbabwe to be the first hyperinflationary economy of the 21st century. This caused the abandonment of the ZW\$ and the adoption of the US\$ and other currency such as the Euro and the Rand. This paper discusses the various types of dollarisation before examining the causes and effects of adopting dollarisation as a way to eliminate hyperinflation, and the failure of the banking system to provide domestic currency to both firms and individuals. The paper is important to policymakers because it gives some recommendations on the subject in question, and suggestions for future research direction are indicated.

Keywords: dollarisation, hyperinflation, causes, effects, Zimbabwe

\section{Background}

Zimbabwe is a landlocked country with a population of approximately thirteen million people, and 80 percent of them live in the rural areas (ZimStat, 2012). As surprising as it may sound, Zimbabwe was one of sub-Saharan's most successful countries. The country emerged from independence with a productive private sector and powerful infrastructure (Hobbes 2014). According to (Charkie 2012), during the 1980 independence, and for the sake of national pride, the Zimbabwean dollar (ZW\$) replaced the Rhodesian dollar at the par rate, which was higher than the American dollar (US\$). At its inception, the ZW\$ had an exchange rate of one ZW\$to 1.47 US\$. However, by July 2008 its value had dropped to ZW\$10 billion to 0.33 US\$, which was fuelled by the substantial increase in money supply (Sikwila, 2013), and this led to an upsurge in inflation.

As Zimbabwe was still boasting with their powerful currency, the situation quickly deteriorated in the late 1990 s and saw a series of events leading to the demise of the ZW\$ (Charkie 2012). Hobbes (2014) suggested that the inevitable fall of the Zimbabwean economy started in 1997 when the country faced restless constituents and increasingly popular opposition. War veterans were paid ZW\$50 000 each for the war of independence. In the following year, large troops of the army were sent to the Democratic Republic of Congo to help secure diamond mines and peace and in the year 2000, civil servants had a salary increment of 90 percent.

In 2003, the land reform programme confiscated thousands of commercial farms from white farmers, but its distribution policy was brought into questions because the majority of the recipients hardly knew how to run commercial farming. All of the above assisted in the downfall of agriculture, which was the backbone of the economy (Hobbes 2014). According to Mhute (2012), inflation ballooned to 7982 percent. The government had huge bills that they could not pay and factories did not have the currency to import raw materials, so production dropped and workers were laid off. Power outages increased as the country could not afford to pay its neighbours for coal.

By the end of 2008 the majority of Zimbabwe's business community stopped accepting the ZW\$, and it was suspended indefinitely by the then minister, Tendai Biti (Biti, 2013). At the beginning of 2008, on an 18 month experiment, a few retailers started accepting foreign currency such as the South African Rand (ZAR), the United States Dollar (US\$), 
the Botswana Pula (BWP), the Euro and the British Pound Sterling, as legal tender for transacting. According to Hanke and Kwok (2009), Zimbabwe's economy experienced macroeconomic imbalances that saw a monthly inflation rising to 79.6 billion percent between 2000 and 2008, which caused a drop in the gross domestic product of 40 percent, unemployment rate of over 80 percent, external payment arrears of US\$3.07 billion, and a high budget deficit of ZW\$1760 quadrillion. The country was spending more, and at the same time, producing less. The caveat to Zimbabwe hyperinflation that led to the adoption of dollarisation started in the year 2000.

\section{Clarification of Concepts and Types of Dollarisation}

Dollarisation is the adoption of the US\$ by the authorities of a country outside United States as the legal tender and the official currency (Forbes et al. 2013;). Forbes et al. (2013) and Ortis (1983) also refer to the process of dollarisation as currency and asset substitution. Schuler (2005) and Hila and Dean (2004) link the concept of dollarisation close to a kind of fixed exchange rate system, implying that a country abandons its own currency as its means of payment or exchange for all transaction purposes. However, it is a means of saving in hard currency, which is asset substitution, (Alvarez-Plata and Garcia-Herrero 2007). Therefore, dollarisation can also be equated to eurorisation or randification, which is the use of the same foreign currency in all trading assets and holding of assets within a region or country.

According to Makochekanwa (2007), there are three stages to dollarisation; unofficial, semi-official and official. "Official or full dollarisation occurs when a country makes a foreign currency (currencies) full legal tender and reduces its own currency, if any, to a subsidiary role and issued only in coins having small values. Generally, under such arrangement, there will be no risk of domestic currency, no currency risk, and therefore, no risk of currency crisis" (Bogetic, 2000). With official dollarisation, the foreign currency (currencies) adopted will not only be a legal tender for use among private parties, but will also be used by the government. One of the main features of full dollarisation, according to Borensztein and Berg (2000), is that once adopted, it will be permanent, or nearly permanent. Compared to currency board, full dollarisation will be relatively more difficult to reverse than doing away with or modifying a currency board. In other words, when a country officially dollarises, its central bank has to withdraw the local currency from circulation and replace it with US dollars or the anchor currency as is the case in Zimbabwe.

Unofficial dollarisation, which is also known as de facto dollarisation, is the spontaneous adoption of the dollar by the general public without support from government legislation, a process in Zimbabwe from 2000 to 2009 (Forbes et al. 2013; Chitambara 2009). For Chitambara (2009) the unofficial dollarisation may also take the guise of currency substitution, asset substitution and liability substitution. This implies circulation of foreign currency among the general public without the approval from officials, meaning that if a person is found in possession of foreign currency, he or she will be arrested. During this period, foreign currency will dominate in the black market.

During semi-official dollarisation, countries use foreign currency as secondary legal tender. However, the foreign currency circulates widely within the country. Semi-officially dollarised countries maintain a domestic central bank and conduct their own monetary policy (Ronnholm, 2007). According to Makochekanwa (2007), that means that foreign currency will be permitted to be used partially alongside the domestic currency. Prices will be tagged in either foreign currency or domestic currency, as this allows monetary institutions to erect foreign licensed shops. For instance in 2008, the Reserve Bank of Zimbabwe (RBZ) announced foreign licensed shops/businesses that were allowed carry out business using foreign currency, among which were some from the hospitality industry.

It is not the first time dollarisation is adopted by an African country; so far, 25 African countries have implemented a dollarisation policy. The dollarisation policy has been adopted by many countries at different times. In most cases, according to Sikwila (2013), countries that have adopted foreign currency as an official legal tender had a background of economic, social and political disturbances that led to instability and poor economic growth. Some countries used foreign currencies due to colonisation, or adopted the currency from their former colonisers. Table 1 shows an extract and improvement of Kurt Schuler's (2005:121-123) and Sakwila's (2013: 403) tables of African countries that adopted dollarisation in the past. Table 2 shows the list of non-African countries that adopted dollarisation. 
Table 1: Selected 25 African countries that adopted dollarization

\begin{tabular}{|l|c|c|c|}
\hline \multicolumn{1}{|c|}{ Country } & Period of dollarisation & Country & Period of dollarisation \\
\hline Angola & Present & Namibia & $1906-1914 ; 1962-1993$ \\
\hline Botswana & $1950-1976$ & Nigeria & $1891-1913$ \\
\hline Cameron & $1910-1916$ & Seychelles & $1903-1919$ \\
\hline Egypt & $1856-1898$ & Sierra Leon & $1898-1913$ \\
\hline Eretria & $1900-1952 ; 1962-1993$ & Somalia & $1920-1950$ \\
\hline Gambia & $1902-1913$ & Swaziland & $1921-1974$ \\
\hline Ghana & $1896-1913$ & Tanzania & $1893-1907 ; 1916-1920$ \\
\hline Kenya & $1896-196-1898$ & Togo & $1904-1914$ \\
\hline Lesotho & $1921-1980$ & Tunisia & $1873-1906$ \\
\hline Liberia & $1880-1985$ & Uganda & $1906-1920$ \\
\hline Libya & $1912-1943$ & Western Sahara & 1930 -present \\
\hline Madagascar & $1886-1926$ & Zimbabwe & 2009 -present \\
\hline Morocco & 1800 s-1969 & - & - \\
\hline
\end{tabular}

Source: Sikwila (2013:403) and Schuler (2005:121-123)

Table 2: List of some non-African countries that used dollarization

\begin{tabular}{|c|c|c|}
\hline Asia & Europe & America \\
\hline Russia & Austria & Mexico \\
\hline Azerbaijan & Croatia & Nicaragua \\
\hline China & Germany & Uruguay \\
\hline Turkey & Greece & Ecuador \\
\hline Taiwan & Hungary I & El Salvador \\
\hline Cambodia & Poland & Brazil \\
\hline Georgia & Ukraine & Argentine \\
\hline Singapore & Yugoslavia & Peru \\
\hline Saudi Arabia & Kosovo & Panama \\
\hline Vietnam & Cyprus & Bolivia \\
\hline UAE & Vatican City & Cuba \\
\hline Yemen & Hungary II & Honduras \\
\hline Nepal & - & Puerto Rico \\
\hline
\end{tabular}

Source: Compiled by current authors

In the case of Zimbabwe, from 2000 until 2008 the country sustained its economy using unofficial dollarisation. It was only at the beginning of 2009 that the Minister of Finance, Tendai Biti, officially announced that the use of other currencies such as the Rand, Pula, Euro, Pound and the US Dollar were permissible for trade. Very recently, Zimbabwe added a new currency to their multi-currency basket. As from 29 January 2014, four new currencies are a legal tender in Zimbabwe, the Australian Dollar, Chinese Yuan, Indian Rupee and Japanese Yen; this means that there are at least eight currencies in circulation in Zimbabwe. The country has turned to the East in an effort to try to ease the economic meltdown. One may think that the result of this partnership could be the increased trade and investments between Zimbabwe and those countries. It should be noted that this type of dollarisation is the first of its kind in the world, and has had many different reactions from the every corner of the world. Therefore, introduction of these four, new, weaker currencies might have a negative impact, as it will bring confusion to everyone.

\section{Causes and Effects of Dollarisation in Zimbabwe}

The major causes of hyperinflation that lead Zimbabwe to dollarise its economy include money printing (seigniorage), foreign currency shortages (with their resultant black market premium), demand pull-inflation (due to disrupted production activities, especially in the agricultural sector), and imported/cost-push inflation (Makochekanwa, 2007).

The Zimbabwean government had no any other solutions to their problems other than printing more money with 
additional zeros. This was evidenced by the unbudgeted government expenditure of 1997 to pay the war veterans gratuities; the publicly condemned and unjustifiable intervention in the Democratic Republic of Congo's (DRCs) war in 1998; the expenses of the controversial land reform which started in 2000; the parliamentary (2000/2005) and presidential (2002) elections; introduction of senators in 2005 (at least 66 posts) as part of 'widening the think tank base'; and the international payment obligations, especially since 2004 , all of which resulted in massive money printing by the government. Because of the above-mentioned reasons, the printing machines had also been the government's solution for such expenses as civil servants' salaries and as a result, this contributed towards the loss in value of the ZW\$ (Makachekanwa, 2007).

According to Mhute (2012), an immediate and noticeable effect of dollarisation was price stability and reduced hyperinflation. After the dollar was introduced, inflation in Zimbabwe remained in single digit figures, and was even negative at the beginning of 2009. Businesses were better able to plan because there was more predictability of key indicators. Mhute (2012) went on to emphasise that the strength of the dollar, however, proved to be a negative factor as it reduced competitiveness of local products in the international market, meaning that foreign companies selling their products in Zimbabwe profited because of higher prices charged in Zimbabwe. This did not do any favours for the economy as it meant that profits made by these foreign businesses were not retained in Zimbabwe as deposits, or through re-investment to improve products, so they do not contribute to growing the economy (Mhute 2012).

Kararach et al. (2010) stated that the out of control inflation was stabilised. This in turn stabilised the overall economy, sustained the buying power of the Zimbabwean people, and allowed the nation as whole to experience significant economic growth. "The long term economic planning is easier to do under the stable currency, and the hope is that the dollar will attract foreign, direct investment that was elusive during the hyperinflationary era. After dollarisation generally all manufacturing industries in Zimbabwe started showing positive changes" (Mutengezanwa et al. 2012).

After capable farmers were driven off their farms through the Fast Track Land Reform Programme (FTLRP) in 2003 , and replaced with farmers, the majority of whom lacked expertise and equipment, revenue from these activities fell by a large percentage. Most of these white farmers where removed violently, and that reduced the number of tourists dramatically. As a result, this fuelled the increasing shortage of foreign currency, as tourism was also a big foreign currency earner for the country (Mhute 2012). However, according to Zunga (2009), there was a strong comeback in the Zimbabwean hospitality industry since dollarisation, thus increasing foreign currency. Occupancy has now grown by 32 percent due to an increase in the numbers of tourists.

Lower transaction costs are also evident, since the country is using an anchor currency, which in most cases is highly traded and convertible. In this instance the US\$ or the South African Rand, and other currencies when compared to when the local currency was used, transaction costs in international trade and investments is, reduced as it there is no need for currency conversions. During the country's hyperinflation period, because of the non-convertibility of the ZW\$, transaction costs of doing international business were very high when using the ZW\$ (Meyer et al, 2004).

For instance, if a buyer from Zimbabwe wanted to import from Japan, the buyer had to first convert the ZW\$ to US\$, and then convent US\$ into Japanese yen. Because of hyperinflation and the shortage of the US\$ in Zimbabwe's banks, the buyer had to purchase the US\$ from the expensive foreign currency black market, and this meant exorbitant transaction costs. On the other hand, in the case of dollarisation with the US\$ as the anchor currency, the Zimbabwean buyer will simply do one conversion from US\$ to Yen, thus reducing transaction costs (of importing in this example). The major cost of dollarisation, especially to a country like Zimbabwe, is forfeiture of seigniorage. Seigniorage is the interest income a central bank earns by issuing non-interest bearing money to buy interest-bearing assets (Burdekin 2008; Makochekanwa 2009). A country's central bank is part of its government; hence, that income is part of the government's revenues.

\section{Conclusion and Recommendations}

The objective of this paper was to explore an understanding of the causes and effects of dollarisation in Zimbabwe. It was however, seen that dollarising was a necessary step to avoid what had turned into a disaster of catastrophic proportions from spiralling into unsustainable levels, as currently most people are living in a vicious circle of poverty. This paper argues that dollarisation has brought happiness and positive social, political and economic change among the people of Zimbabwe.

Dollarisation brought about overnight elimination of hyperinflation; there is a visible reduction in exchange rate volatility and a reduction in capital flight. To those who had different ideas as a whole, pinned their arguments on that dollarisation causes the rich to become richer and the poor to become poorer. Therefore, this could be another area of future research. In addition, it is not clear for how long the economy of Zimbabwe will remain dollarised but for now, it is 
the only notable solution in eradicating poverty and hyperinflation. There is available evidence that dollarisation had a positive impact on the performance of the economy of Zimbabwe, and should be allowed to continue for the good of the people, as it has been a great starting point in building up an economy that went down in shreds. In case Zimbabwe decided to end its dollarisation policy, this paper suggests that currency pegging should be the starting point, even if it would be a short time pain but for a long term solution.

Dollarisation was the single most important policy introduced by the Zimbabwean coalition government, since the country had already utilised all its foreign reserves. Therefore, this paper recommends Zimbabwe keep using the United States Dollar as its main currency in circulation because:

- Price stability and inflation is reduced and is at a normal rate

- The Zimbabwean people can sustain and allow the nation as whole to experience significant economic growth

- Investors are satisfied with security and policies from the Zimbabwean government, in order for them to reinvest in the country again

- Every working person has a reasonable disposable income if paid in dollars, rather than any other currency.

\section{References}

Alvarez-Plata. P. and Garcia-Herero, A. 2007. To Dollarize or de dollarize: consequences for monetary policy, Asian Development Bank. Berger, S.2008. Final humiliation for the Zimbabwe dollar as foreign currency legalised. The Telegraph. 10 September 2008. http://www.telegraph.co.uk

Biti, T. (2013). Minister of Finance: The 2013 National Budget Statement. Government of Zimbabwe.

Bogetic, Z. (2000). Official dollarisation: current experiences and issues. Cato Journal, 20(2), 179-213.

Borensztein, E., \& Berg, A. (2000). Full dollarisation. IMF policy discussion paper. Washington, D.C.: International Monetary Fund.

Burdekin, R. C. (2008). Currency boars vs dollarisation: lessons from the Cook Island. Cato Journal, 28(1), 101-114.

Charkie, P. (2012). Was dollarisation a success in Zimbabwe? A case of a banking sector. [Online] Available: http://www.studymode.com/essays/was-dollarisation-a-success-in-Zimbabwe-1226423-html (February 4, 2014).

Chitambara, P. (2009). Unpacking dollarisation (part one). Unpublished document.

Forbes, K., Sebastian, V., Mapingure, C., Mirimi, K., Chimutingidza, F., \& Mataruse, R. (2013). Employee perceptions of dollarisation and the hospitality industry performance. Australian Journal of Business and Management Research, 2(10), 31-37.

Hanke, S. H., \& Kwok, A. K. F. (2009). On the management of Zimbabwe's hyperinflation. Cato Journal, 29(2), 353-363.

Hila, A., \& Dean, J.W (2004). Distributional effects of dollarisation. Latin American Case, Third World Quarterly, 25(3), 461-482.

Hobbes, M. (2014). How did Zimbabwe become so poor- and yet so expensive? The shockingly high prices of one of Africas most impoverished countries. [Online] Available: <http://www.newrepublic.com/artcle/115925 (February 4, 2014).

Kararach.G., Kadenge, P., and Guvheya, G. (2010). Currency reforms in Zimbabwe: An analysis of possible currency regime. The African capacity Building Foundation, Occasional Paper № 1.

Makochekanwa A. (2007). A dynamic enquiry into the causes of hyperinflation in Zimbabwe. Working Paper Series No. 9. Department of Economics. University of Pretoria. South Africa.

Makochekanwa, A. (2009). Zimbabwe Currency's Crisis: Which Currency to adopt aftermath multi currency Regime? MPRA, Paper 22463.

Meyer, J. P., Becker, T. E., \& Vandenberghe, C. (2004). Employee commitment and motivation: A conceptual analysis and integrative model. Journal of Applied Psychology, 89(6), 991-1007.

Mhute, T. (2012). Dollarisation in Zimbabwe: Cause and effect. Consultancy Africa Intelligence's Finance and Economy Unit. [Online] Available on www.consultancyafrica.com

Mutengezanwa, M., Mauchi, F. N., Njanike, K., Matanga, J., \& Gopo, R. N. (2012). The possibility of reintroducing the Zimbabwean Dollar. Australian Journal of Business and Management Research, 2(6), 01-08.

Ortiz, G. (1983). Dollarisation Mexico: Causes and consequences. Journal of Money, Credit and Banking, 15(2), 174-185.

Ronnholm, G. (2007). The dollarisation process in Ecuadorian and El-Salvador- the motives, the political and economic outcomes and effects. Department of Political Science, Stockholm University.

Schuler, K. (2005). Some theory and history of dollarisation. Cato Journal, 25(1), 115-125.

Sikwila, M. N. (2013). Dollarisation and the Zimbabwe's Economy. Journal of Economics and Behavioral Studies, 5(6), 398-405.

Zimbabwe National Statistic Agency. (2012). Quarterly Digest of Statistics, Government of Zimbabwe.

Zunga, N. (2009). Zimbabwe hospitality sector -Undeniable long term value given the country prime tourism assets. IMARA investing. 